\title{
STUDI KARAKTERISTIK KARKAS BABI BALI ASLI DAN BABI LANDRACE YANG DIGUNAKAN SEBAGAI BAHAN BAKU BABI GULING
}

\author{
SRIYANI, N. L. P. DAN I N.T. ARIANA \\ Fakultas Peternakan Universitas Udayana Denpasar Bali \\ sriyaninlp@yahoo.co.id
}

\begin{abstract}
ABSTRAK
Tujuan penelitian ini adalah untuk mengetahui perbedaan karakteristik karkas dari dua jenis breed babi yaitu babi bali asli dan babi landrace sebagai bahan baku babi guling. Rancangan yang digunakan yaitu rancangan acak lengkap dengan 2 jenis babi yaitu babi bali dengan manajemen pemeliharaan tradisional dan babi landrace dengan manajemen pemeliharaan intensif. Umur kedua jenis babi sebagai sampel penelitian berkisar 2-3 bulan. Data diuji dengan menggunakan $\mathrm{T}$ Test (Two Independent Tes). Penelitian ini dilaksanakan di rumah potong hewan tradisional babi yang khusus memotong babi untuk kebutuhan babi guling. Hasil penelitian menunjukkan berat potong babi bali yang digunakan untuk bahan baku babi guling $16,17 \mathrm{~kg}$ lebih rendah $(\mathrm{P}<0,05)$ daripada babi landrace sebesar 35,06 kg. Berat karkas babi bali 10,77 kg lebih rendah $(\mathrm{P}<0,05)$ daripada babi landrace sebesar 25,65kg. Persentase karkas babi bali 66,98 \% nyata lebih rendah $(\mathrm{P}<0,05)$ daripada babi landrace sebesar 73,12 \%. Nilai fleshing index karkas babi bali 0,22 nyata lebih rendah $(\mathrm{P}<0,05)$ daripada karkas babi landrace sebesar 0,38 . Tebal lemak punggung babi bali 11,2 $\mathrm{mm}$ nyata lebih tinggi $(\mathrm{P}<0,05)$ daripada babi landrace sebesar 8,1 $\mathrm{mm}$. Berdasarkan hasil dari penelitian ini dapat disimpulkan bahwa kualitas karkas babi bali yang diperlihatkan oleh variabel karakteristik karkas lebih rendah daripada karkas babi landrace.
\end{abstract}

Kata kunci: karkas,babi bali,babi landrace

\section{CHARACTERISTICS OF BALI PIG AND LANDRACE PIG CARCASS USED AS A RAW MATERIAL FOR SUCKLING PIG}

\begin{abstract}
This study aims to determine the differences of carcass characteristics of the two different breeds, such as bali pig and landrace pig. These domesticated animals used as raw material for suckling pig. A complete randomized design (CRD) was used with two different pigs, bali pig with traditional maintenance management and landrace pig with intensive maintenance management. Both species were used as samples between 2-3 months. They are tested using $\mathrm{T}$ Test (Two Independent Tests). The research was conducted at traditional slaughter housing for the needs of suckling pig. It showed that $16.17 \mathrm{~kg}$ weight of bali pig used for suckling pig which is significantly lower $(\mathrm{P}<0.05)$ than $35.06 \mathrm{~kg}$ of landrace pigs. The carcass weight of bali pig is $10.77 \mathrm{~kg}$ significantly lower $(\mathrm{P}<0.05)$ than $25.65 \mathrm{~kg}$ of landrace pig. The percentage of bali pig carcass is $66.98 \%$ significantly lower $(\mathrm{P}<0.05)$ than $73.12 \%$ landrace pigs. The value of fleshing index of bali pig carcass is 0.22 significantly lower $(\mathrm{P}<0.05)$ than 0.38 landrace pigs. Back fat thickness of bali pigs is $11.2 \mathrm{~mm}$ significantly higher $(\mathrm{P}<0.05)$ than $8.1 \mathrm{~mm}$ landrace pigs. It can be concluded that the quality of bali pig carcass is lower better compared to landrace pig carcass.
\end{abstract}

Keywords: carcass, bali pig, landrace pig

\section{PENDAHULUAN}

Kota Denpasar dan di pulau Bali pada umumnya, sebagian besar masyarakat memanfaatkan babi bali asli dan babi landrcae untuk digunakan sebagai bahan baku babi guling. Babi bali asli memiliki segmen pasar/ konsumen yang khusus terutama bagi konsumen yang menggunakan babi bali sebagai sarana upacara maupun konsumsi untuk pembuatan babi guling. Tingginya peminat konsumen untuk menggunakan babi bali asli sebagai produk guling menimbulkan kesulitan industri babi guling untuk menyediakan bahan baku. Beberapa permasalahan pada pemeliharaan babi lokal antara lain kecepatan produksi yang relatif lebih rendah daripada 
bangsa babi landrace dan penyediaan bibit yang terbatas menjadi penyebab langkanya peredaran babi bali sebagai bahan baku lokal.

Perbedaan penampilan produksi dari kedua bangsa babi ini sudah banyak diungkap. Namun perbedaan karakteristik karkas dari kedua bangsa babi ini belum banyak diteliti, khususnya perbedaan karaktersitik karkas yang dipergunakan sebagai bahan baku babi guling. Penelitian ini penting untuk dilaksanakan agar konsumen menadapatkan informasi spesifikasi produk babi guling yang berasal dari bahan baku dari kedua bangsa babi tersebut. Penelitian ini akan dilaksanakan di rumah potong hewan tradisional babi yang khusus memotong babi untuk kebutuhan babi guling. Informasi yang akan dicari di rumah potong ini adalah, berat potong,berat karkas,panjang karkas,tebal lemak punggung dan fleshing index karkas babi bali dan babi landcrace yang akan digunakan sebagai bahan baku babi guling. Informasi ini penting di sampaikan kepada konsumen agar bisa digunakan sebagai acuan dalam memilih bahan baku babi guling yang berasal dari breed berbeda.

\section{MATERI DAN METODE}

\section{Materi}

Materi yang digunakan dalam penelitian ini adalah babi bali dan babi landrace yang akan digunakan sebagai bahan baku babi guling. Babi ini dipotong di rumah potong hewan tradisional sekaligus tempat pembuatan babi guling. Umur babi yang dipotong di tempat pemotongan ini menurut informasi dari pemilik industri babi guling ini berumur 2-3 bulan baik pada babi bali maupun babi landrcae.

\section{Lokasi dan Waktu Penelitian}

Pengambilan data dilaksanakan di rumah potong milik Bapak I Wayan Patra yang berlokasi di Banjar Peginding, Desa Dalung, Kecamatan Kuta Utara yang merupakan tempat pembuatan dan pemesanan babi guling.

\section{Rancangan Penelitian}

Pada penelitian ini, rancangan yang digunakan yaitu rancangan acak lengkap (RAL), dengan 2 jenis babi yang berbeda yaitu : 1) babi bali dengan manajemen pemeliharaan secara tradisional (A1) dan 2) yaitu babi landrace dengan manajemen pemeliharaan secara intensif. Babi hidup ditimbang terlebih dahulu sebelum dilaksanakan pemotongan untuk mendapatkan data berat potong. Setelah dilakukan pemotongan maka dilaksanakan pengambilan data karakteristik karkas yang lain yaitu yaitu berat karkas, \% karkas, panjang karkas, tebal lemak punggung dan fleshing index.

\section{Variabel Penelitian}

1. Berat potong. Berat hidup ternak babi sesaat sebelum dipotong. Babi yang akan digunakan untuk babi guling ditimbang dengan menggunakan timbangan gantung kapasitas 50 $\mathrm{kg}$.

2. Berat karkas. Berat potong dikurangi darah,jeroan (isi saluran pencernaan). Khusus untuk karkas babi guling maka kepala dan seluruh kaki di masukkan ke dalam berat karkas karena dalam membuat babi guling kepala babi dan kaki diikutkan dalam produk babi guling.

3. Persentase berat karkas. Persentase berat karkas dihitung berdasarkan perbandingan antara berat karkas panas dengan berat potong dikalikan 100\%. Rumus persentase karkas:

$$
\% \text { karkas }=\frac{\text { Berat Karkas }}{\text { Berat Potong }} \times 100 \%
$$

4. Panjang Karkas. Panjang karkas diukur dari tulang rusuk pertama sampai dengan tulang bagian depan samping pubis (Boggs dan Merkel, 1984).

5. Tebal Lemak Punggung. Tebal lemak punggung didapat dari hasil pengukuran menggunakan alat metal ruler yang ditusukkan pada punggung antara tulang rusuk 10 dengan 11 dan lihat angka yang ditunjukan oleh alat tersebut lalu catat hasilnya.

6. Fleshing Index. Fleshing index merupakan rasio perbandingan antara berat karkas segar $(\mathrm{kg})$ dengan panjang karkas $(\mathrm{cm})$.

\section{Analisis Statistik}

Data yang diperoleh dianalisis menggunakan Two Independent Sample T- test (Steel dan Torrie, 1989).

\section{HASIL DAN PEMBAHASAN}

Hasil penelitian berdasarkan analisis perbandingan dengan menggunakan uji Two Independent Sample T-test (Steel dan Torrie, 1989) disajikan pada Tabel 1. Rata-rata berat potong babi bali asli yang digunakan untuk bahan baku babi guling sebesar $16,7 \mathrm{~kg}$ nyata lebih rendah daripada babi landrace sebesar $35 \mathrm{~kg}(\mathrm{P}<0,05)$. Rata-rata berat karkas babi bali asli sebesar $10 \mathrm{~kg}$ nyata lebih rendah daripada babi landrace sebesar $25,29 \mathrm{~kg}$ $(\mathrm{P}<0,05)$. Persentase karkas babi bali asli sebesar 66,98 $\%$ nyata lebih rendah daripada babi landrace sebesar $73,12 \%(\mathrm{P}<0,05)$. Panjang karkas babi bali asli sebesar $49,10 \mathrm{~cm}$ nyata lebih rendah daripada babi landrace sebesar $67,18 \mathrm{~cm}(\mathrm{P}<0,05)$. Lebar karkas babi bali asli sebesar 20,07 cm nyata lebih rendah daripada babi landrace sebesar 23,35 $\mathrm{cm}(\mathrm{P}<0,05)$. 
Tabel 1. Tabel profil karkas babi bali asli dan babi landrace yang digunakan sebagai bahan baku babi guling.

\begin{tabular}{lrrr}
\hline \multirow{2}{*}{ Variabel } & \multicolumn{2}{c}{ Perlakuan } & \multirow{2}{*}{ SEM ${ }^{1)}$} \\
\cline { 2 - 4 } & $16,17^{\mathrm{a} 2)}$ & $35^{\mathrm{b}}$ & 0,67 \\
Berat Potong (kg) & $10^{\mathrm{a}}$ & $25,59^{\mathrm{b}}$ & 0,48 \\
Berat Karkas (kg) & $66,98^{\mathrm{a}}$ & $73,12^{\mathrm{b}}$ & 2,35 \\
Persentase Karkas (\%) & $49,10^{\mathrm{a}}$ & $67,18^{\mathrm{b}}$ & 0,92 \\
Panjang Karkas (cm) & $20,07^{\mathrm{a}}$ & $25,65^{\mathrm{b}}$ & 0,53 \\
Lebar Karkas (cm) & $0,21^{\mathrm{a}}$ & $0,38^{\mathrm{b}}$ & 0,007 \\
FI (Fleshing Index) & $11,11^{\mathrm{b}}$ & $8,1^{\mathrm{a}}$ & 0,12 \\
\hline TLP (Tebal Lemak Punggung) (mm) & & &
\end{tabular}

Keterangan :

1) SEM = Standar Error of the Threatment Means

2) Nilai rata-rata pada baris yang sama dengan huruf yang berbeda dibelakangnya adalah signifikan $(\mathrm{P}<0,05)$.

Nilai fleshing index karkas babi bali asli sebesar 0,22 nyata lebih rendah daripada babi landrace sebesar o,38 $(\mathrm{P}<0,05)$. Tebal lemak unggung karkas babi bali asli sebesar 11,2 $\mathrm{mm}$ nyata lebih tinggi daripada babi landrace sebesar 8,1 mm ( $\mathrm{P}<0,05)$.

Hasil analisis statistik dengan menggunakan uji T-test menunjukan bahwa berat potong daging babi bali nyata $(\mathrm{P}<0,05)$ lebih rendah dibandingkan daging babi landrace. Hal ini disebabkan karena perbedaan bangsa dari kedua jenis babi tersebut yang mengakibatkan potensi genetik yang berbeda. Babi bali merupakan babi yang didatangkan dari Tiongkok dan lama-kelamaan menjadi babi asli di Bali. Babi bali secara genetik pertumbuhannya lebih lambat dibandingkan babi babi ras impor. Sedangkan babi landrace merupakan babi unggul yang berasal dari Denmark. Jenis ini merupakan ternak babi yang diseleksi untuk produksi bacon. Babi landrace adalah babi yang diternakkan untuk meningkatkan produksi daging di Indonesia. Babi ini termasuk babi tipe daging (bacon) yang berkualitas. Sifat-sifat yang menguntungkan dari babi ini mudah dipelihara, mempunyai kemampuan beradaptasi yang cukup tinggi, kualitas daging lebih baik. Perbedan sistem pemeliharaan juga menjadi alasan berat potong babi bali nyata lebih rendah daripada babi landrace. Babi bali dipelihara secara tradisional (ekstensif) dengan sistem perkandangan seadanya. Babi diikat atau dikandangkan pada kandang sederhana, tidak diberikan konsentrat buatan pabrik dan tidak melakukan vaksinasi secara berkala (Budaarsa et al., 2014). Pakan yang diberikan seadanya berupa pakan hijauan antara lain: batang pisang, lamtoro, daun tibah, daun kelor, daun lamtoro, eceng gondok, daun papaya serta dicampur dengan dedak padi dan polar (Budaarsa et al., 2014). Sementara Babi landrace adalah babi yang dipelihara secara intensif dengan pakan bernutrisi tinggi dan kandang sesuai kebutuhan babi (Sihombing, 1997).

Berat karkas, \% karkas, panjang karkas dan lebar karkas babi bali asli yang digunakan sebagai bahan baku babi guling nyata lebih rendah daripada babi landrace. Hal ini disebabkan karena perbedaan bangsa dari kedua jenis babi tersebut yang menimbulkan perbedaan potensi genetik. Babi bali asli merupakan bangsa babi lokal yang belum mendapatkan tindakan pemuliaan. Genetik babi landrace adalah jenis babi unggul dan penghasil daging dengan kualtas yang baik. Disamping itu faktor berbedaan pemeliharaan juga dapat menyebabkan lebih rendahnya profil karkas pada babi bali asli dibandingkan dengan babi landrcae. Pemeliharaan babi bali yang dipelihara dengan ektensif, tanpa dikandangkan dan diberi makanan seadanya tentu saja memiliki produksi karkas yang lebih rendah daripada babi landrace yang dipelihara dengan sistem intensif, dikandangkan dan diberi makanan konsentrat komersial. Kualitas karkas yang baik adalah karkas yang lebih banyak bagian dagingnya daripada bagian tulang dan lemak (Seputra, 2004). Persentase berat karkas dipengaruhi oleh pakan, jenis kelamin, bangsa babi, bobot hidup dan umur serta persentase non karkas (Judge et al., 1989). Selanjutnya dijelaskan bahwa semakin meningkatnya berat hidup, biasanya persentase karkas juga meningkat dan sebaliknya persentase non karkas menurun. Pada penelitian ini pola berat potong diikuti oleh pola berat karkas, semakin tinggi berat potong menghasilkan persentase karkas yang tinggi.

Nilai fleshing index karkas babi bali yang digunakan sebagai bahan baku babi guling secara statistik nyata lebih rendah daripada babi landrace. Perbedaan bangsa atau genetik dan perbedaan manajement pemeliharaan menjadi alasan rendahnya nilai FI pada babi bali asli dibandingkan dengan nilai FI pada babi landrace. Fleshing index merupakan rasio antara berat karkas dengan panjang karkas. Nilai FI yang lebih tinggi menunjukkan konformasi karkas yang lebih baik yaitu perototan pada karkas lebih tebal. Nilai FI memberi gambaran tentang jumlah daging (otot dan lemak) yang dikandung pada sebuah karkas.

Tebal lemak punggung pada babi bali yang digunakan sebagai bahan baku babi guling secara statistik nyata lebih tinggi daripada babi landrace. Hal ini disebabkan karena perbedan breed antara babi bali dengan babi landrace. Babi babi adalah breed babi tipe lemak (lord type) yang cenderung menyimpan lemak lebih baik daripada breed babi lain seperti babi landrace yang tipe bakon (bacon type). Ukuran tebal lemak punggung secara tidak langsung menggambarkan produksi lemak atau daging. Tebal lemak punggung babi yang tipis memberi persentase hasil daging yang tinggi dan sebaliknya tebal lemak punggung yang tinggi memberi hasil persentase hasil daging yang rendah. Bisa diartikan tebal lemak punggung pada babi bali yang lebih tinggi daripada babi landrace pada penelitian 
ini akan menghasilkan persentase daging yang lebih rendah, dan ini dari segi produksi karkas tidak baik karena daging merupakan komponen dari karkas yang bernilai ekonomi tinggi.

Rendahnya tebal lemak punggung babi landrace juga disebabkan babi landrace dipelihara secara intensif dan diberi pakan komersial. Pakan yang dikonsumsi babi landrace mempunyai kandungan protein tinggi yang memenuhi kebutuhan tubuh yang kemungkinan menyebabkan lemak dapat dimanfaatkan dengan efisien sebagai energi, akibatnya lemak yang dimanfaatkan di dalam tubuh tidak terlalu tinggi (Tobing, 2012). Peningkatan protein dalam pakan dapat meningkatan kandungan protein dan menurunkan lemak daging (Soeparno, 2009). Pemberian pakan dengan komposisi berbeda akan menghasilkan komposisi kimia daging yang berbeda pula. Pakan dengan kandungan energi tinggi yang dikonsumsi oleh ternak dapat menghasilkan deposisi lemak dalam tubuh yang tinggi, dan penurunan kadar protein dan air.

\section{SIMPULAN}

Berdasarkan hasil dari penelitian ini dapat disimpulkan bahwa kualitas karkas babi bali lebih rendah daripada karkas babi landrace. Hal ini dapat dilihat pada variabel berat potong, berat karkas, persentase karkas, panjang karkas, lebar karkas nilai fleshing index babi bali yang digunakan untuk bahan baku babi guling nyata lebih rendah daripada babi landrace. Tebal lemak punggung babi bali yang digunakan sebagai bahan baku babi guling nyata lebih tinggi daripada babi landrace.

\section{UCAPAN TERIMA KASIH}

Ucapan terimakasih disampaikan kepada Direktorat Jendral Pendidikan Tinggi melalui Hibah Unggulan Udayana. Terimakasih juga penulis sampaikan kepada staf laboratorium Teknologi Hasil Ternak Fakultas Peternakan Universitas Udayana.

\section{DAFTAR PUSTAKA}

Budaarsa ,K., N. Tirta. A, K. Mangku Budiasa dan P. A. Astawa. 2014. Eksplorasi hijauan pakan babi dan cara penggunaannya pada peternakan babi tradisional di Provinsi Bali. Fakultas Peternakan Universitas Udayana. Vol. 17 No. $1: 26-30$.

Boggs, D. L. and R. A. Merkel. 1984. Live Animal Carcass Evaluation and Selection Manual. Toronto, Ontario, Canada. Kendal/Hunt Publishing Company.

Judge, M. D., Aberle, E. D., Forrest, J. C., Hedrick, H. B., and R. A. Merkel. 1989. Palatability and Cookery of Meat. In Principles of Meat science p. 275. Kendall/ Hunt Dubuque IA.

Steel, R. G. D. dan J. H. Torrie. 1989. Prinsip dan Prosedur Statistika. Diterjemahkan oleh Bambang Sumantri. Gramedia Pustaka. Jakarta.

Seputra, I M. A. 2004. Penampilan dan Kualitas Karkas Babi Landrace yang diberi Ransum Mengandung Limbah Tempe. Tesis. Universitas Udayana, Bali.

Soeparno. 2009. Ilmu dan Teknologi Daging. Cetakan V. Gadjah Mada University Press. Yogyakarta.

Sihombing D.T.H. 1997. Ilmu Ternak Babi. Cetakan pertama. Gadjah Mada University Press. Yogyakarta.

Tobing, S. W. L. 2012. Perbandingan Kualitas Karkas dan Daging antara Babi Peliharaan dengan Babi Hutan. Program Pascasarjana Universitas Andalas. Padang. 